\title{
Nitrogen removal from sewage and septage in constructed wetland mesocosms using sand media amended with biochar
}

\author{
P. de Rozari ${ }^{\mathrm{a}, \mathrm{b}, *}$, M. Greenway ${ }^{\mathrm{b}}$, A. El Hanandeh ${ }^{\mathrm{b}}$ \\ a Department of Chemistry, Faculty of Science and Engineering, Nusa Cendana University, Kupang, Indonesia \\ ${ }^{\mathrm{b}}$ Griffith School of Engineering, Griffith University, Nathan, Brisbane, Australia
}

\section{A R T I C L E I N F O}

\section{Keywords:}

Biochar

Plant biomass

Nitrogen

Secondary sewage

Septage

Vertical flow wetland mesocosms

\begin{abstract}
A B S T R A C T
Biochar has been identified as a media amendment to improve nutrient removal from wastewater, and $\mathrm{N}$ retention and plant growth in agroforestry. It therefore has the potential for treating domestic wastewater. The aim of this research was to compare nitrogen removal and plant growth in pure sand and sand amended with biochar, in wetland mesocosms $(240 \mathrm{~L})$ receiving sewage. There were seven media treatments based on the proportions of biochar in the sand media (100\% sand, sand and coir peat, 5, 10, 15, 20, 25\% biochar). The plant species were Paperback tree (Melaleuca quinquenervia) and Lemongrass (Cymbopogon citratus). The mesocosms were continuously loaded for 8 months with secondary clarified wastewater (SCW) (16 L/day). Septage was then intermittently loaded ( $20 \mathrm{~L} / 2$ days) for a further 8 months. Inflow and outflow samples were monitored for TN, $\mathrm{NH}_{4}-\mathrm{N}$, and $\mathrm{NO}_{\mathrm{x}}-\mathrm{N}$.

All treatments showed good nitrogen removal efficiency. Average removal efficiencies of TN, $\mathrm{NO}_{\mathrm{x}}-\mathrm{N}^{\text {and }} \mathrm{NH}_{4}-$ $\mathrm{N}$ in the mesocosms loaded with SCW ranged from 71 to $87 \%, 81$ to $93 \%$ and 65 to $79 \%$, for $100 \%$ Sand to $25 \%$ Biochar respectively. For septage, the removal efficiencies ranged from 63 to $81 \%, 69$ to $87 \%$ and 66 to $81 \%$, for $100 \%$ Sand to $25 \%$ Biochar respectively. Significant differences of nitrogen outflow concentrations were observed between pure sand and sand amended with biochar. Physical chemical properties of the biochar would have facilitated microbial processes and adsorption. Strong positive correlations were observed between biochar content in the media and nitrogen removal rates. The increased nitrogen removal may be attributed to higher mineralisation of organic nitrogen and $\mathrm{NH}_{4}-\mathrm{N}$, especially in the case of septage where strong correlation was observed between $\mathrm{BOD}_{5}$ and TN removal. Total $\mathrm{N}$ biomass in the plants harvested after 21 months ranged from 13.4-14.0 $\mathrm{g}$ N. The addition of biochar did not increase plant $\mathrm{N}$ biomass in either species.
\end{abstract}

\section{Introduction}

Constructed wetlands (CWs) are an efficient eco-technology for wastewater treatment with the advantages of low cost, simple operation and maintenance (Kadlec and Wallace, 2008). CWs can be used to treat domestic wastewater to reduce biological oxygen demand, total suspended solids, coliforms and nutrients (Abou-Elela et al., 2013; De Rozari et al., 2015, 2016; Wu et al., 2015). They can be constructed using local materials which reduce construction cost considerably (Lucas and Greenway, 2011a; Zurita et al., 2009). The challenges in this technology are to find local materials which can effectively remove nutrients for a long term application.

Media is an important component of the CWs. It is used to control either the rate of water infiltration or retention time, filter sediments and particulates, provide sorption surfaces for nutrients, provide surface biofilms, and provide a nutrient source for microbes (bacteria, fungi, protozoan, algae) and macrophytes (Kadlec and Wallace, 2008). The majority of nitrogen removal takes place in the media via sorption, and microbial processes including ammonification, nitrification, denitrification, and anaerobic ammonium oxidation (anammox) (Saeed and Sun, 2012). Media also influences the hydraulic conductivity $\left(\mathrm{K}_{\mathrm{sat}}\right)$ and hydraulic retention time (HRT) which are important factors affecting nitrogen removal efficiency (Lucas and Greenway, 2011b; Zhang et al., 2015). Better removal efficiency of nitrogen is correlated with low infiltration and/or slow hydraulic conductivity (Davis et al., 2006; Lucas and Greenway, 2011a).

Several studies have focused on nitrogen $(\mathrm{N})$ removal using different media (e.g., Millot et al., 2016; Wu et al., 2015; Zhang et al., 2012; Zurita et al., 2009). Zhang et al. (2015) reviewed the performance of CWs in tropical and sub-tropical regions and concluded that the media

\footnotetext{
* Corresponding author at: Department of Chemistry, Faculty of Science and Engineering, Nusa Cendana University, Kupang, Indonesia.

E-mail addresses: phderozari@yahoo.com, philiphi.derozari@griffithuni.edu.au (P. de Rozari), m.greenway@griffith.edu.au (M. Greenway), a.elhanandeh@griffith.edu.au (A. El Hanandeh).
} 
significantly affected the removal efficiencies of $\mathrm{TN}, \mathrm{NH}_{4}-\mathrm{N}$, and $\mathrm{NO}_{3}-\mathrm{N}$ in vertical flow constructed wetland (VFCW) systems.

Removal efficiency may be enhanced by augmenting sand or gravel media with other material that may facilitate nitrogen removal. Since biochar has high organic carbon content, this material can serve as a soil conditioner to improve the physicochemical and biological properties of the soil. Mohan et al. (2014) reported that biochar added into the soil could increase nutrient availability, microbial activity, soil organic matter, water retention and crop production. In laboratory scale, Gupta et al. (2015) compared the efficiency of biochar media made from Oak tree (Quercus $s p$ ) and gravel in CWs planted with Canna sp for nitrogen removal from synthetic wastewater. The results showed that nitrogen removal was higher in the CW with biochar media. Kizito et al. (2017) compared the nitrogen removal efficiency in vertical flow (VF) columns loaded with anaerobic digested effluent. They reported that columns packed with biochar media (from corn cob and wood biochar) performed significantly better than those packed with gravel media. Zhou et al. (2017) also reported that biochar made from bamboo enhanced the nitrogen removal efficiency in aerated VFCW systems compared to gravel systems. Therefore, biochar may be a suitable amendment to enhance nitrogen removal in CWs. However, the findings reported in the literature are mainly based on laboratory scale experiments under laboratory controlled conditions and in many cases used synthetic wastewater (Kizito et al., 2017; Sarkhot et al., 2012; Yao et al., 2012; Gupta et al., 2015; Zhou et al., 2017). Our study investigated the nitrogen removal efficiency in vertical flow mesocosms using sand media augmented with biochar planted with two plant species (Melaleuca quinquenervia and Cymbopogon citratus) under field environmental conditions and using domestic wastewater from both secondary clarified wastewater (SCW) and septage. This paper compares (1) hydraulic conductivity, (2) nitrogen removal (TN, $\mathrm{NH}_{4}-\mathrm{N}$ and $\mathrm{NO}_{\mathrm{x}}-\mathrm{N}$ ), and (3) $\mathrm{N}$ uptake in 2 plant species (Melaleuca quinquenervia and Cymbopogon citratus) in pure sand media and sand media augmented with biochar.

\section{Methods}

\subsection{Experimental design}

The experiments were conducted from November 2013 to July 2015 using $240 \mathrm{~L}$ vertical flow (VF) mesocosms. Sand sourced from river sand was the media while biochar produced from hardwood using fast pyrolysis processes at $500{ }^{\circ} \mathrm{C}$ was the amendment. There were seven different media treatments augmented with biochar content of $0-25 \%$ with $5 \%$ increments of biochar. The treatments contained $12 \%$ coir peat to enhance moisture retention (during intermittent loading) except in a control treatment that used $100 \%$ sand with no added coir peat, labelled as S100. The physical and chemical characteristics of the seven media treatments were presented in a previous paper (De Rozari et al., 2016). All treatments were triplicated. Each mesocosm was planted with one Melaleuca tree (Melaleuca quinquenervia) and one Lemongrass plant (Cymbopogon citratus).

Wastewater was stored in three 5,000 L tanks and each tank fed the seven treatment mesocoms (Fig. 1). The outlet was located at the bottom of mesocosm and elevated with a hose to approximately $5 \mathrm{~cm}$ below the media surface. Wastewater was replenished monthly. The experiment was divided into three phases: establishment phase - the mesocosms intermittently received tertiary wastewater effluent (November 2013-February 2014)-; continuous secondary clarified wastewater load phase (March-October 2014) with a hydraulic loading rate $16 \mathrm{~L} /$ day; and intermittent septage load phase (November 2014-July 2015 ) with $20 \mathrm{~L}$ of septage effluent loaded every two days. The removal of TSS, $\mathrm{BOD}_{5}$, and coliforms has previously been reported in De Rozari et al. (2015). Phosphorus removal, microbial P biomass and plant-P biomass has been reported in De Rozari et al. (2016). This paper focuses on $\mathrm{N}$ removal and plant- $\mathrm{N}$ biomass.

\subsection{Hydraulic conductivity}

Hydraulic conductivity measurements were determined by falling head measurements and were carried out in February 2014, August 2014 and March 2015 for each mesocosm. The reading at the lip (max ponding depth) and distance from lip to the top of the outlet (outlet depth) were measured. The wastewater was added into the mesocoms when they were still draining. The depths were determined from the soil surface to water height. The elevation was measured in each mesocosm by reading the estimated depth at the middle of the meniscus. The measurements were carried out in 5-min intervals for at least $45 \mathrm{~min}$ (until the wastewater had drained).

The determination of saturated hydraulic conductivity $\left(\mathrm{K}_{\text {sat }}\right)$ was calculated based on the equation adapted from Bedient and Huber (1988):

$$
\begin{gathered}
K_{\text {sat }}=\frac{A_{t} L}{A_{m}\left(t_{2}-t_{1}\right)} \ln \left(\frac{h_{1}}{h_{2}}\right) \\
\mathrm{A}_{\mathrm{t}}=\text { average ponding area }\left(\mathrm{m}^{2}\right) \\
\mathrm{A}_{\mathrm{m}}=\text { average media cross-sectional area }\left(\mathrm{m}^{2}\right) \\
\mathrm{L}=\text { media depth }(\mathrm{m}) \\
\mathrm{h}_{1}=\text { initial head }(\mathrm{m}) \\
\mathrm{h}_{2}=\text { final head }(\mathrm{m}) \\
\mathrm{t}=\text { elapse time (hours) }
\end{gathered}
$$

\subsection{Water sample collection}

The inflows and outflows were sampled every two weeks for the first four months (March-June 2014) and then monthly from August 2014 to July 2015. The inflows were collected from the inlet hose which was connected to the tank and the outflows were collected from a $135 \mathrm{~L}$ collection chamber connected to the mesocosm (Fig. 1). The collection chamber stored the outflow from the mesocosm for approximately two weeks. After collection, samples were refrigerated at $4{ }^{\circ} \mathrm{C}$, then frozen until analysed. For $\mathrm{NH}_{4}-\mathrm{N}$ and $\mathrm{NO}_{\mathrm{x}}-\mathrm{N}$, the samples were filtered using $0.45 \mu \mathrm{m}$ Millipore filters. The filtered solutions were then analysed using colorimetric methods with a Discrete Chemistry Analyser (Westco Smartchem 200, Danbury CT, USA) according to USEPA 350.1, USEPA 353.2 (USEPA, 1983). To determine TN, the standards and samples were first digested using standard persulphate methods according to standard methods 4500-P (APHA, 2005) and analysed using colorimetric methods with a Discrete Chemistry Analyser (Westco Smartchem 200, Danbury CT, USA) according to the methods for chemical analysis of water and waste (USEPA, 1983).

\subsection{Plant samples}

Determination of biomass was carried out by harvesting aboveground and belowground biomass. The Melaleuca trees were separated into stems, branches, leaves, bark and roots while the Lemongrass plants were separated into shoots, rhizome and roots. These samples were oven dried for $48 \mathrm{~h}$ at $70^{\circ} \mathrm{C}$ to obtain a constant dry weight. Representative samples of oven dried plants from each plant part were ground and pelletised, then analysed for TN in a mass spectrometer (Sercon Hydra 20-22) according to Gautam and Greenway (2014). Plants in treatments BC5, BC10, BC15 and BC25 were harvested in March 2015 and the remaining plants (S100, SCP and BC20) were harvested in July 2015.

\subsection{Statistical and data analysis}

All statistical analyses were carried out using SPSS 21 software. The mean and standard deviation of saturated hydraulic conductivity $\left(\mathrm{K}_{\mathrm{sat}}\right)$ were determined and One-way ANOVA test was applied to determine the significant differences $\mathrm{K}_{\text {sat }}$ among the treatments. A Tukey post-hoc 

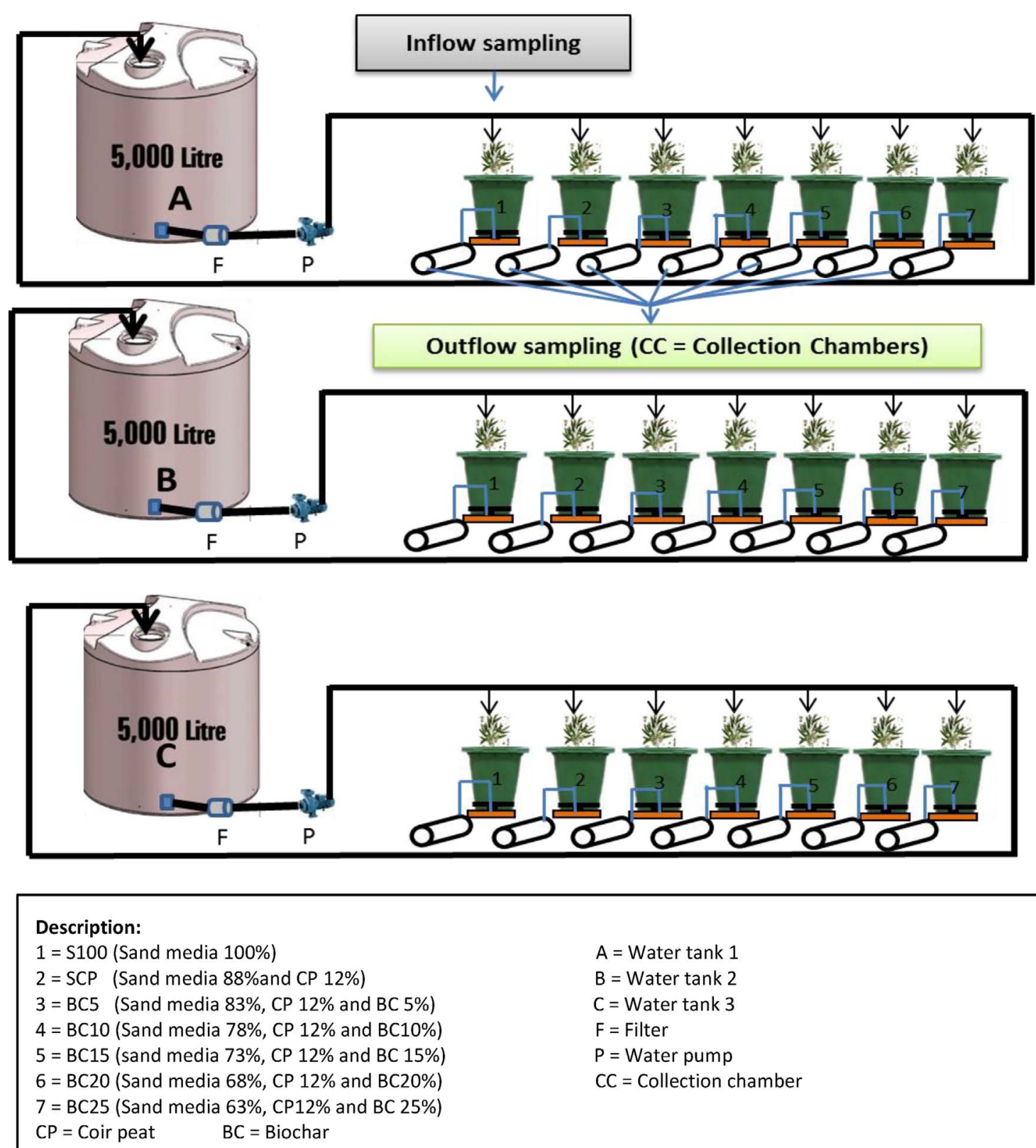

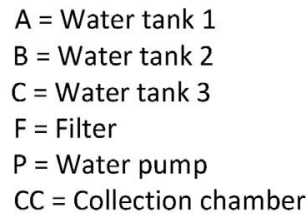

Fig. 1. Schematic of experimental layout of VF mesocosms. test was carried out to decide the significant difference of $\mathrm{K}_{\text {sat }}$ among the treatments.

For nitrogen, the mean and standard deviation of inflow and outflow concentrations were calculated. The percentage removal efficiency was calculated as $\% \mathrm{R}=\frac{C_{i n-} C_{e f}}{C_{i n}} x 100 \%$ where $\mathrm{C}_{i n}$ and $\mathrm{C}_{e f}$ are inflow and outflow of $\mathrm{TN}, \mathrm{NH}_{4}-\mathrm{N}$ and $\mathrm{NO}_{\mathrm{x}}-\mathrm{N}$ concentration. One-way ANOVA analyses were applied to test for differences among treatments for each parameter. Tukey HSD post-hoc tests were then carried out to determine which treatments were significantly different. In all cases, significant level ( $\alpha=0.05)$ was used. Regression analysis was carried out to investigate the effects of biochar content on the removal efficiency of the different nitrogen compounds.

For plant biomass $\mathrm{N}$, the mean and standard deviation of biomass $\mathrm{N}$ from each treatment were determined. The significant differences among the four treatments harvested in March (BC5, BC10, BC15 and BC25) and the three treatments harvested in July 2015 (S100; SCP and BC20) were assessed using One-way ANOVA. The Tukey post-hoc tests ( $\alpha=0.05$ ) was conducted to determine the significant difference of biomass $\mathrm{N}$ among the subsets.

\section{Results and discussion}

\subsection{Hydraulic conductivity}

Saturated hydraulic conductivity $\left(\mathrm{K}_{\text {sat }}\right)$ across the seven treatments in February 2014, August 2014 and March 2015 are shown in Table 1. The highest $K_{\text {sat }}$ during these experiments was in the sand media without the addition of biochar (S100) and the lowest $\mathrm{K}_{\text {sat }}$ in sand media with the addition of $25 \%$ biochar (BC25). One-way ANOVA analysis showed that there was no significant difference of $\mathrm{K}_{\text {sat }}$ between S100 and SCP, indicating the addition of coir peat in the sand media did not influence hydraulic conductivity. No significant differences of $\mathrm{K}_{\text {sat }}$ were also found among BC5, BC10 and BC15 and among BC15, BC20 and BC25, respectively. Tables 1 and 2 show that the addition of biochar in the sand media reduced the $\mathrm{K}_{\mathrm{sat}}$ when it was higher than $15 \%$. Barnes et al. (2014) also reported that the addition of biochar in sand 
Table 1

Saturated hydraulic conductivity $(\mathrm{cm} / \mathrm{h})(x \pm S D)$ in VF mesocosms with seven different treatments.

\begin{tabular}{llll}
\hline \multirow{2}{*}{ Treatment } & \multicolumn{3}{l}{ Sampling event } \\
\cline { 2 - 4 } & February 2014 & August 2014 & March 2015 \\
\hline S100 & $94.3 \pm 9.1$ & $106.2 \pm 6.6$ & $108.9 \pm 9.1$ \\
SCP & $92.6 \pm 8.7$ & $102.9 \pm 9.6$ & $100.6 \pm 8.2$ \\
BC5 & $82.2 \pm 9.1$ & $86.9 \pm 1.3$ & $86.8 \pm 5.7$ \\
BC10 & $80.9 \pm 1.0$ & $86.8 \pm 4.6$ & $86.6 \pm 2.3$ \\
BC15 & $67.1 \pm 3.0$ & $75.1 \pm 3.2$ & $75.6 \pm 1.7$ \\
BC20 & $63.0 \pm 2.5$ & $69.7 \pm 5.0$ & $70.8 \pm 4.5$ \\
BC25 & $61.3 \pm 4.9$ & $62.9 \pm 10.1$ & $65.8 \pm 2.9$ \\
\hline
\end{tabular}

Table 2

Significant differences of $\mathrm{K}_{\text {sat }}$ among the treatments $(\alpha<0.05)$.

\begin{tabular}{llllllll}
\hline & S100 & SCP & BC5 & BC10 & BC15 & BC20 & BC25 \\
\hline S100 & - & - & $+\cdot$ & $+\cdot$ & $\mathrm{x}+\cdot$ & $\mathrm{x}+\cdot$ & $\mathrm{x}+\cdot$ \\
SCP & - & - & - & - & $\mathrm{x}+\cdot$ & $\mathrm{x}+\cdot$ & $\mathrm{x}+\cdot$ \\
BC5 & $+\cdot$ & - & - & - & - & $\mathrm{x}$ & $\mathrm{x}+\cdot$ \\
BC10 & $+\cdot$ & - & - & - & - & - & $\mathrm{x}+\cdot$ \\
BC15 & $\mathrm{x}+\cdot$ & $\mathrm{x}+\cdot$ & - & - & - & - & - \\
BC20 & $\mathrm{x}+\cdot$ & $\mathrm{x}+\cdot$ & $\mathrm{x}$ & - & - & - & - \\
BC25 & $\mathrm{x}+\cdot$ & $\mathrm{x}+\cdot$ & $\mathrm{x}+\cdot$ & $\mathrm{x}+\cdot$ & - & - & - \\
\hline
\end{tabular}

$\mathrm{x}$ : significant difference of $\mathrm{K}_{\text {sat }}$ sampling in February $2014(\alpha<0.05)$.

+ : significant difference of $\mathrm{K}_{\mathrm{sat}}$ sampling in August $2014(\alpha<0.05)$.

$\because$ significant difference of $\mathrm{K}_{\text {sat }}$ sampling in March $2015(\alpha<0.05)$.

- : no significant differences.

decreased $\mathrm{K}_{\text {sat }}$ due to porosity, bulk density and the internal structure of biochar.

$\mathrm{K}_{\text {sat }}$ initially increased between February 2014 and August 2014 (Table 1). However, statistical analysis revealed there were no significant differences of $\mathrm{K}_{\text {sat }}$ value between February 2014, August 2014 and March 2015. The initial increase of $K_{\text {sat }}$ could be caused by the growth of plant roots. Plant roots would have maintained the $\mathrm{K}_{\text {sat }}$ after loading with septage thereby preventing clogging.

\subsection{Nitrogen ( $\mathrm{TN}, \mathrm{NH}_{4}-\mathrm{N}$, and $\left.\mathrm{NO}_{x}-\mathrm{N}\right)$ : water samples}

The addition of biochar to the sand media will incur additional costs as biochar is more expensive than sand. Therefore, the effectiveness of nitrogen removal in the media treatments was compared to pure sand media (S100). Statistical analysis revealed that the outflow nitrogen concentrations of S100 were not significantly different with SCP (Tables 3 and 5). However, significant differences of $\mathrm{TN}$ and $\mathrm{NH}_{4}-\mathrm{N}$ were observed between pure sand media (S100) and biochar media treatments which were higher than $5 \%$ biochar (> BC5). Regarding $\mathrm{NO}_{\mathrm{x}}$, significant differences were found between the pure sand media (S100)

Table 3

Significant differences of $\mathrm{TN}, \mathrm{NH}_{4}-\mathrm{N}$, and $\mathrm{NO}_{\mathrm{x}}-\mathrm{N}$ loaded with secondary clarified wastewater among the treatments $(\alpha<0.05)$.

\begin{tabular}{llllllll}
\hline & S100 & SCP & BC5 & BC10 & BC15 & BC20 & BC25 \\
\hline S100 & - & - & $\mathrm{x}$ & $+\mathrm{x} \cdot$ & $+\mathrm{x} \cdot$ & $+\mathrm{x} \cdot$ & $+\mathrm{x} \cdot$ \\
SCP & - & - & - & $+\mathrm{x}$ & $+\mathrm{x}$ & $+\mathrm{x} \cdot$ & $+\mathrm{x} \cdot$ \\
BC5 & $\mathrm{x}$ & - & - & - & $+\mathrm{x}$ & $+\mathrm{x}$ & $+\mathrm{x}$ \\
BC10 & $+\mathrm{x} \cdot$ & $+\mathrm{x}$ & - & - & - & $+\mathrm{x}$ & $+\mathrm{x}$ \\
BC15 & $+\mathrm{x} \cdot$ & $+\mathrm{x}$ & $+\mathrm{x}$ & - & - & - & - \\
BC20 & $+\mathrm{x} \cdot$ & $+\mathrm{x} \cdot$ & $+\mathrm{x}$ & $+\mathrm{x}$ & - & - & - \\
BC25 & $+\mathrm{x} \cdot$ & $+\mathrm{x} \cdot$ & $+\mathrm{x}$ & $+\mathrm{x}$ & - & - & - \\
\hline
\end{tabular}

$\mathrm{x}$ : significant difference of TN $(\alpha<0.05)$.

+ : significant difference of $\mathrm{NH}_{4}-\mathrm{N}(\alpha<0.05)$.

$\because$ significant difference of NOx-N $(\alpha<0.05)$

-: no significant differences. and the media augmented with more than $10 \%$ biochar ( $>\mathrm{BC} 10$ ). Nevertheless, no significant differences were observed between BC10 and BC15; and between BC20 and BC25 (Tables 3 and 5). Results and discussion are focused on nitrogen removal in S100, BC5, BC10 and $\mathrm{BC} 20$ and are presented for (1) the continuous secondary clarified wastewater load phase and (2) intermittent septage load phase.

\subsubsection{Continuous secondary clarified wastewater load phase (March- October 2014)}

The inflow concentrations of $\mathrm{TN}, \mathrm{NH}_{4}-\mathrm{N}$, and $\mathrm{NO}_{\mathrm{x}}$-in SCW ranged from $2.9-4.0 \mathrm{mg} / \mathrm{L}, 0.12-0.17 \mathrm{mg} / \mathrm{L}$, and $0.7-0.9 \mathrm{mg} / \mathrm{L}$, respectively (Fig. 2). The mean concentrations of TN in the outflows from SCW ranged from 0.37 (BC20) -1.2 (S100) $\mathrm{mg} / \mathrm{L}$ (Fig. 2), corresponding to removal percentages of $71-85 \%$ (Table 4 ). The highest outflow concentrations were observed in the pure sand media (S100), meanwhile the lowest outflow concentrations were observed in the sand media amended with $20 \%$ biochar (BC20). The TN concentrations in the outflows decreased with the increase of biochar content in the sand media as shown in Fig. 2a. A clear trend suggesting a strong positive correlation $(r=0.945)$ between biochar content in the media and TN removal percentages was observed (Fig. 3). One-way ANOVA analysis revealed there was no significant difference of TN between S100 and SCP (Table 3), confirming that the addition of coir peat did not contribute to the removal of total nitrogen from secondary clarified wastewater (SCW). Significant differences were observed between pure sand media (S100) and the media amended with more than $5 \%$ biochar ( $>$ BC5). This indicated that the presence of biochar reduced TN concentrations in the outflows. Further statistical analysis revealed that significant differences occurred between treatments when the biochar content in the media exceeded $10 \%$ increments (i.e., SCP and BC10; BC5 and BC15; BC10 and BC20).

Outflow concentrations of $\mathrm{NH}_{4}-\mathrm{N}$ ranged from 0.03 (BC20) -0.06 $(\mathrm{S} 100) \mathrm{mg} / \mathrm{L}$ while the outflow concentrations of $\mathrm{NO}_{\mathrm{x}}-\mathrm{N}$ ranged from 0.04 (BC20) - 0.17 (S100) mg/L (Fig. 2). The pure sand media (S100) had the highest outflow concentrations of $\mathrm{NH}_{4}-\mathrm{N}$ and $\mathrm{NO}_{\mathrm{x}}-\mathrm{N}$ in each sampling period while the sand media amended with $20 \%$ of biochar (BC20) had the lowest concentrations. One-way ANOVA tests showed significant differences between $\mathrm{NH}_{4}-\mathrm{N}$ concentrations in $10 \%$ increments of biochar. However, for $\mathrm{NO}_{\mathrm{x}} \mathrm{-N}$, the biochar only made a significant difference when the biochar content exceeded $10 \%$.

Average removal efficiencies ranged from 65 (S100) to 77\% (BC20) for $\mathrm{NH}_{4}-\mathrm{N}$ and 82 (S100) to $92 \%$ (BC20) for $\mathrm{NO}_{\mathrm{x}}-\mathrm{N}$ (Table 4). Regression analysis further revealed a strong positive correlation between the percentage of biochar in the media and $\mathrm{NH}_{4}-\mathrm{N}(\mathrm{r}=0.908)$ and $\mathrm{NO}_{\mathrm{x}}-\mathrm{N}$ $(\mathrm{r}=0.8150)$ removal efficiencies, respectively (Fig. 3). Thus, an increase in biochar amendment to sand media increases $\mathrm{NH}_{4}-\mathrm{N}$ and $\mathrm{NO}_{\mathrm{x}^{-}}$ $\mathrm{N}$ removal efficiencies.

\subsubsection{Intermittent septage load phase (November 2014-July 2015)}

Inflow and outflow concentrations are given in Fig. 4. Inflow concentrations for the septage ranged from 101 to $131 \mathrm{mg} / \mathrm{L}, 56-76 \mathrm{mg} / \mathrm{L}$ and $8.9-13.6 \mathrm{mg} / \mathrm{L}$ for $\mathrm{TN}, \mathrm{NH}_{4}-\mathrm{N}$, and $\mathrm{NO}_{\mathrm{x}}-\mathrm{N}$ respectively. Outflow concentrations ranged from 21.5 (BC20) to 44.0 (S100) mg/L for TN, 13.4 (BC20) - 26.4 (S100) mg/L for $\mathrm{NH}_{4}-\mathrm{N}$ and 1.0 (BC20) - 3.6 (S100) $\mathrm{mg} / \mathrm{L}$ for $\mathrm{NO}_{\mathrm{x}}-\mathrm{N}$. Thus, an increased percentage of biochar in sand media was associated with a greater reduction of $\mathrm{TN}, \mathrm{NH}_{4}-\mathrm{N}$, and $\mathrm{NO}_{\mathrm{x}^{-}}$ $\mathrm{N}$ concentrations in the outflows. One-way ANOVA analysis revealed significant differences among mesocosm treatments, confirming that the addition of biochar in the sand media significantly reduced $\mathrm{TN}$, $\mathrm{NH}_{4}-\mathrm{N}$ and $\mathrm{NO}_{\mathrm{x}}-\mathrm{N}$ concentrations in the outflows (Table 5).

Average removal efficiencies ranged from 63 (S100) to 79\% (BC20) for TN, 66 (S100) to 79\% (BC20) for $\mathrm{NH}_{4}-\mathrm{N}$, and 69 (S100) $-87 \%$ (BC20) for $\mathrm{NO}_{\mathrm{x}}-\mathrm{N}$ (Table 6). Regression analysis confirmed that there was a strong positive correlation between percentages of biochar and $\mathrm{TN}(\mathrm{r}=0.910), \mathrm{NH}_{4}-\mathrm{N}(\mathrm{r}=0.901)$, and NOx-N $(\mathrm{r}=0.840)$ removal efficiencies (Fig. 5). 


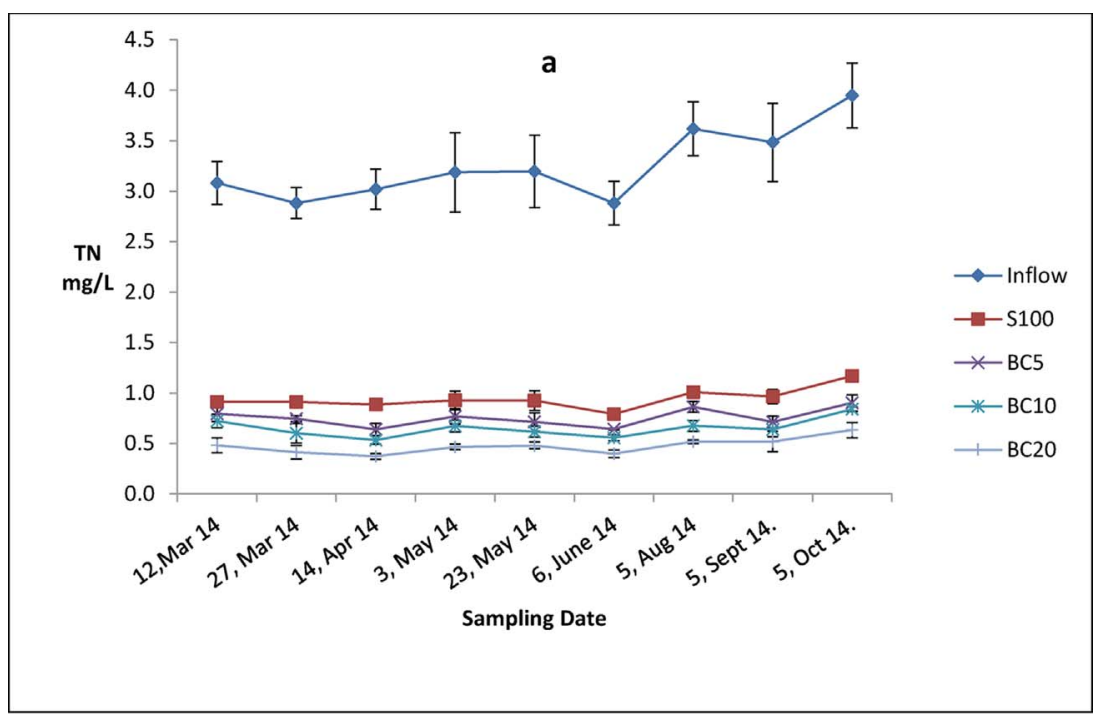

Fig. 2. $\mathrm{TN}(\mathrm{a}), \mathrm{NH}_{4}-\mathrm{N}$ (b) and $\mathrm{NO}_{\mathrm{x}}-\mathrm{N}(\mathrm{c})(x \pm \mathrm{SD})$ concentrations $(\mathrm{mg} / \mathrm{L})$ in VF mesocosms with different media loaded with secondary clarified wastewater.
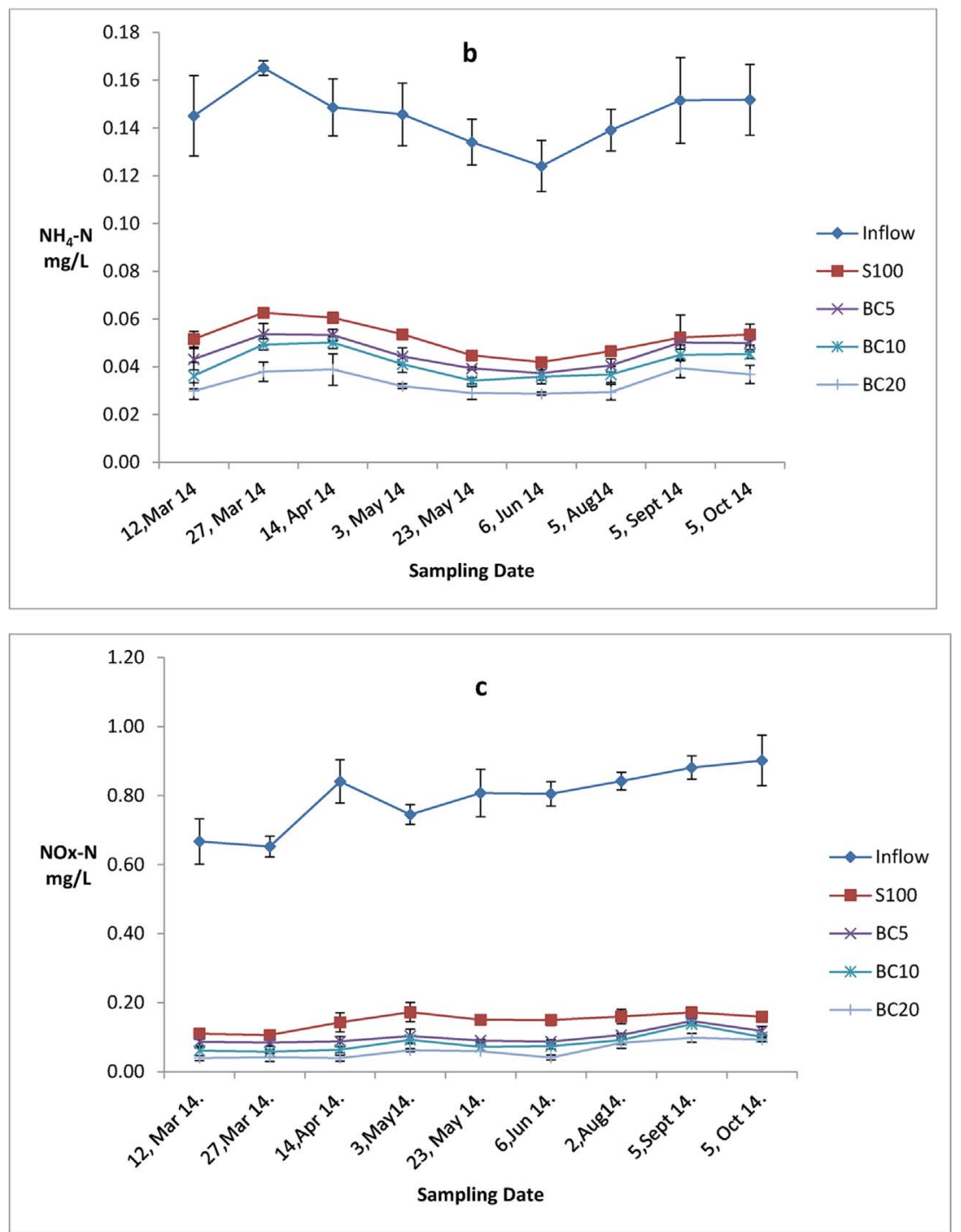

In our research, the pure sand media had a removal efficiency of more than $60 \%$, comparable with the results obtained by Abou-Elela et al. (2013) who reported removal efficiencies of $62 \%$ of ammonia. Our results are also comparable with the nitrogen removal reported by Bradley et al. (2015) from a laboratory scale column experiment using sand media augmented with various percentages of biochar made from poplar (Populus. maximowiczii). They reported that the higher nitrogen removal in the columns was mainly due to adsorption of $\mathrm{NH}_{4}-\mathrm{N}, \mathrm{NO}_{3}-\mathrm{N}$, and organic- $\mathrm{N}$ compounds into the biochar surface areas and microbial $\mathrm{N}$ immobilisation. These processes occur simultaneously in the 
Table 4

Removal efficiency $(x \pm \mathrm{SD})$ of $\mathrm{TN}, \mathrm{NH}_{4}-\mathrm{N}$, and $\mathrm{NO}_{\mathrm{x}}-\mathrm{N}(\%)$ loaded with secondary clarified wastewater.

\begin{tabular}{lllll}
\hline \multirow{2}{*}{ N Species } & \multicolumn{3}{l}{ Media treatment } \\
\cline { 2 - 5 } & $\mathrm{S} 100$ & $\mathrm{BC5}$ & $\mathrm{BC} 10$ & $\mathrm{~B}$ (20 \\
\hline $\mathrm{TN}(\%)$ & $70.9 \pm 1.3$ & $76.6 \pm 1.7$ & $79.8 \pm 1.7$ & $85.2 \pm 1.3$ \\
$\mathrm{NH}_{4}-\mathrm{N}(\%)$ & $65.1 \pm 2.1$ & $68.5 \pm 2.3$ & $71.4 \pm 2.7$ & $76.9 \pm 2.0$ \\
$\mathrm{NO}_{\mathrm{x}}-\mathrm{N}(\%)$ & $81.5 \pm 2.1$ & $87.3 \pm 1.8$ & $89.2 \pm 2.6$ & $92.3 \pm 2.4$ \\
\hline
\end{tabular}

substrate media. Adsorption of $\mathrm{NH}_{4}{ }^{+}$in biochar has been reported by Kizito et al. (2015) who found that rice husk and wood biochar adsorbed $70-80 \%$ of $\mathrm{NH}_{4}-\mathrm{N}$ from piggery manure anaerobic digestate slurry. Zheng et al. (2013) reported that the addition of 5\% biochar (w/ w) made from giant reed (Arundo donax $L$ ) into the soil significantly reduced the cumulative amount of $\mathrm{NH}_{4}{ }^{+}-\mathrm{N}$ and $\mathrm{NO}_{3}{ }^{-}-\mathrm{N}$ leaching from fertiliser through adsorption and microbial N-immobilisation. Yao et al. (2012) investigated 13 types of biochar and reported that 9 types could remove ammonium but had little ability to adsorb nitrate. Güereña et al. (2013), in a four years field trial, reported that clay loam soil amended with maize stover biochar had adsorbed more dissolved $\mathrm{N}$ organic than those without the biochar.

Tan et al. (2015) pointed out that adsorption mechanisms of biochar can occur via different types of interactions such as electrostatic attraction, ion-exchange, physical adsorption and chemical bonding. In our research, increase of biochar percentage in the sand media increased the cation exchange capacity (CEC) from 5.73 (S100) to $9.23 \mathrm{cmol}(+) / \mathrm{kg}$ (BC20) (De Rozari et al., 2016). The CEC in the biochar is the main source of $\mathrm{NH}_{4}{ }^{+}$adsorption (Jassal et al., 2015). It means that the better performance with the addition of biochar in the sand media in removing $\mathrm{NH}_{4}-\mathrm{N}$ could be due to the increase of CEC in the media. The increase of biochar content amended in sand media could increase the specific surface area and porous structure. Thus, both organic and inorganic nitrogen compounds could be adsorbed onto the biochar surfaces and trapped in the porous structure of biochar (Zhang et al., 2015). The Fourier Transform Infrared Spectroscopy (FT-IR) spectra indicated that the biochar used in our research contained carbonyl, carboxyl, aldehyde, ketones and aromatic compounds which could provide negative surface charges (De Rozari et al., 2016). These functional groups could specifically adsorb the ammonium ion $\left(\mathrm{NH}_{4}{ }^{+}\right)$ which has positively charged ions. Wang et al. (2015) reported improvement of $\mathrm{NH}_{4}{ }^{+}$adsorption was attributed to the existing phenolic$\mathrm{OH}$ and carboxyl $\mathrm{C}=\mathrm{O}$ groups because these functional groups provide negative surface charges.

In our research, $\mathrm{NO}_{\mathrm{x}}-\mathrm{N}$ removal efficiency increased with the increase of percentage of biochar in the sand media. Kameyama et al.
(2012) pointed out that nitrate sorption in the biochar surface could be mainly because of the base functional groups and not due to physical sorption. Mukherjee et al. (2011) stated that electrostatic interactions (outer sphere complexation mechanism) are the main process of nitrate adsorption. The addition of biochar in the sand media increased the anion exchange capacity (AEC) from 1.09 (S100) to $1.51 \mathrm{cmol}(-) / \mathrm{kg}$ (BC20) (De Rozari et al., 2016). This confirmed that ion exchange mechanisms could be one of the factors affecting the increase of $\mathrm{NO}_{\mathrm{x}}-\mathrm{N}$ removal efficiency. Further investigation is required to understand the role of ion exchange mechanisms for $\mathrm{NO}_{\mathrm{x}}-\mathrm{N}$ removal in biochar.

Microbial processes promote nitrogen removal. During loading with SCW, the mesocosms were mainly in saturated conditions, thus facilitating more anaerobic conditions whereas loading with septage was intermittent, facilitating more aerobic condition. Nitrogen in CWs has a better removal efficiency in intermittent loading compared to continuous loading (Caselles-Osorio and García, 2007; Saeed and Sun, 2012). Caselles-Osorio and García (2007) found that intermittent loading produced higher ammonium removal efficiency (80-99\%) compared to continuous loading (71-85\%). Intermittent loading promotes nitrification and denitrification simultaneously (Zhou et al., 2017). Gul et al. (2015) reported that the surface charge on biochar could bind with microbial cells, chemical compounds and ions. In addition, high concentrations of nutrients and dissolved organic compounds trapped in the porous structure of the biochar could also promote microbial growth (Gul et al., 2015). Thus, the microbial communities on the biochar surface and within its' pores would enhance nitrogen removal processes.

In our previous study, we reported that the removal efficiency of $\mathrm{BOD}_{5}$ was positively correlated with the biochar content in the media (De Rozari et al., 2015). The relationship between TN removal (\%), $\mathrm{BOD}_{5}$ removal and biochar percentage in the mesocosms loaded with SCW and septage are shown in Fig. 6. Moderate correlation $(r=0.470)$ between $\mathrm{TN}$ removal and $\mathrm{BOD}_{5}$ removal was observed when the mesocosms were loaded with SCW. On the other hand, strong correlation $(r=0.850)$ was observed when the mesocosms were intermittently loaded with septage. This may be explained by the higher organic $\mathrm{N}$ content in the septage which is mineralised to $\mathrm{NH}_{4}-\mathrm{N}$ as well as the higher $\mathrm{NH}_{4}-\mathrm{N}$ content in the septage (Fig. 4) which is mineralised to $\mathrm{NO}_{\mathrm{x}} \mathrm{-N}$ and subsequently denitrified. Higher organic carbon in the organic matter $\left(\mathrm{BOD}_{5}\right)$ would facilitate denitrification and hence the stronger correlation with TN removal.

Biochar in the sand media enhanced the removal of TN because it provided better physical/chemical conditions for microbial growth. Aeration, adsorption and trapping organic material in the micro and meso pore structure of the biochar would all contribute to $\mathrm{N}$ removal. Organic nitrogen compounds would be mineralised by the

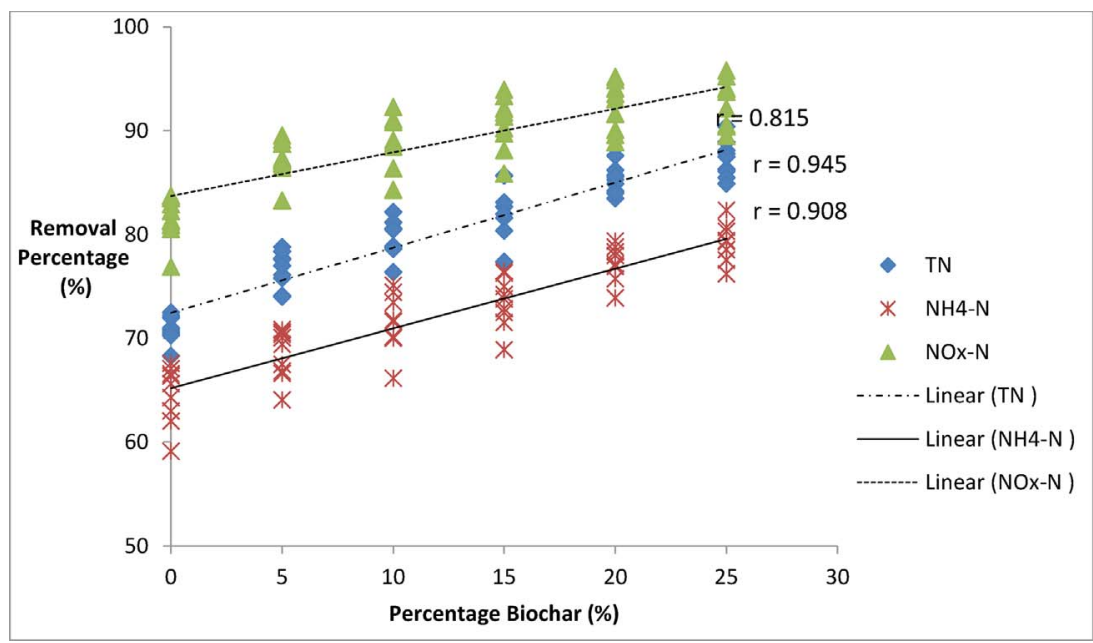

Fig. 3. Regression analyses of biochar content (\%) vs removal percentage of nitrogen compounds (\%) in the VF mesocosms loaded with secondary clarified wastewater. 


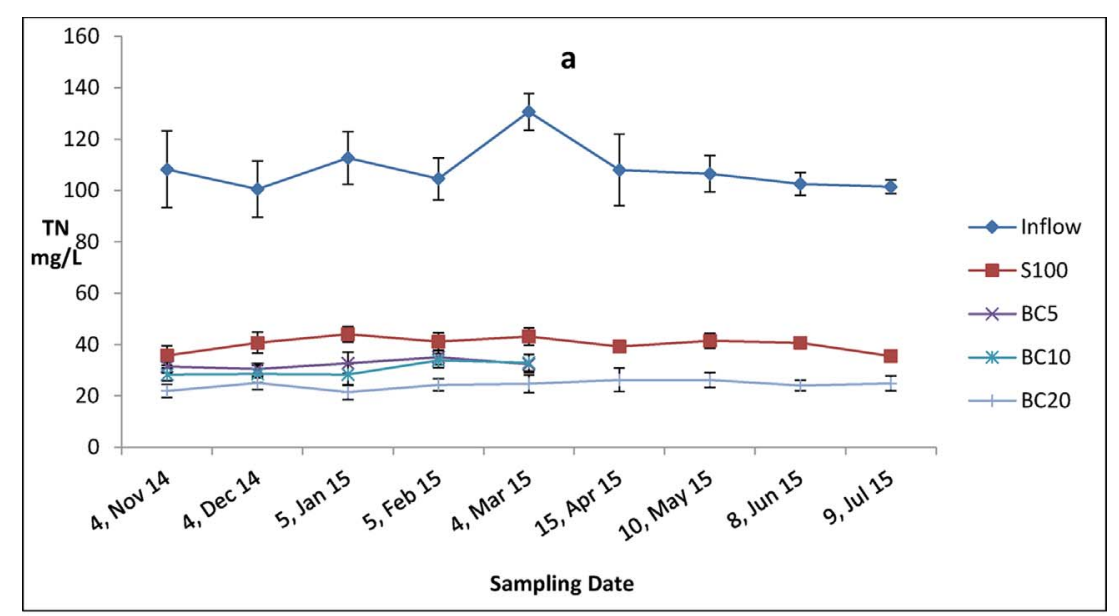

Fig. 4. $\mathrm{TN}(\mathrm{a}), \mathrm{NH}_{4}-\mathrm{N}(\mathrm{b}), \mathrm{NO}_{\mathrm{x}}-\mathrm{N}(\mathrm{c})(x \pm \mathrm{SD})$ concentrations $(\mathrm{mg} / \mathrm{L})$ in VF mesocosms with different media loaded with septage.
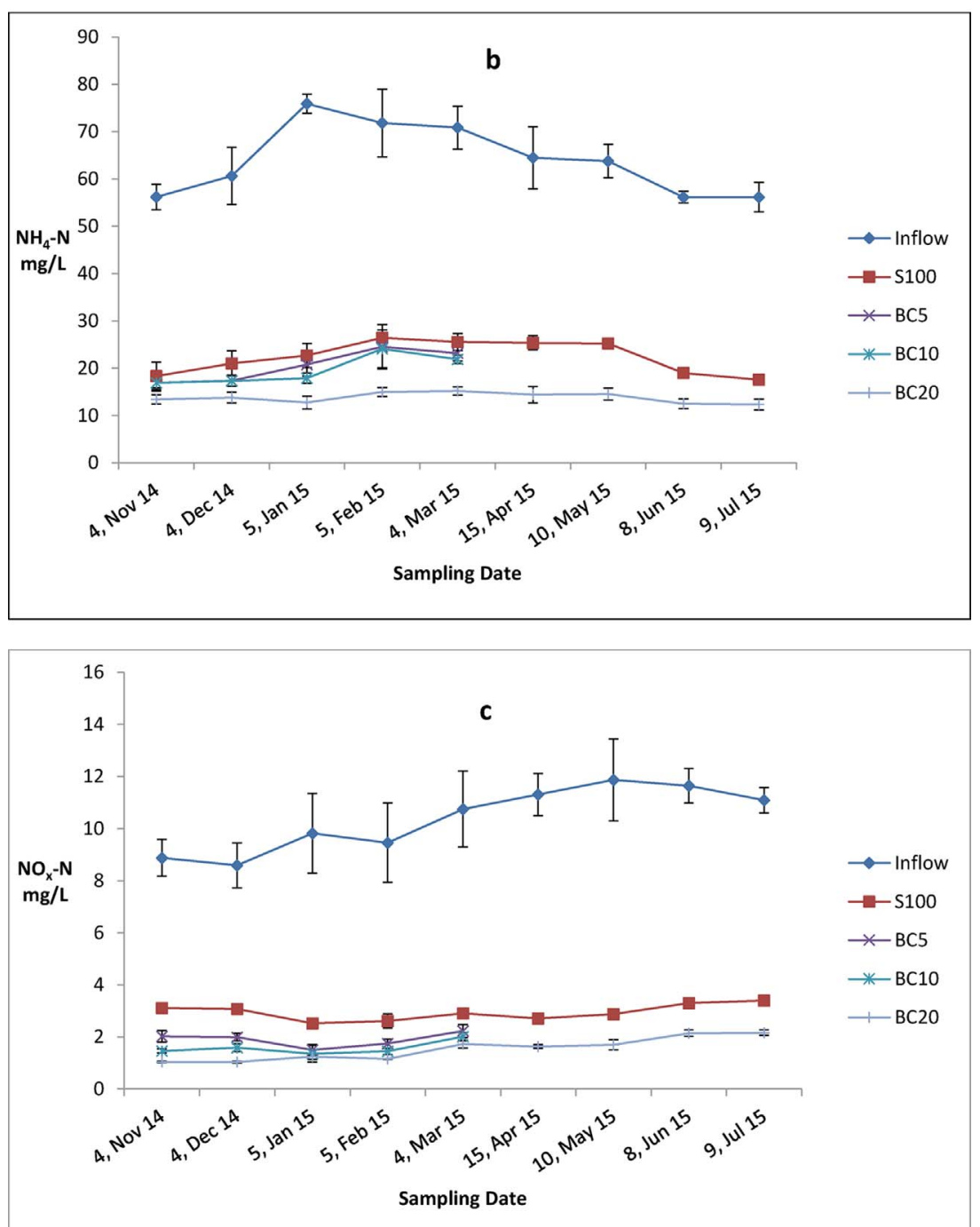

microorganisms and then nitrogen removal could take place through nitrification and denitrification. Further, nitrogen removal/transformations would also take place within the collection chambers where the outflows were stored for approximately two weeks.

\subsection{Plant uptake}

Plant uptake also contributed towards the remove of $\mathrm{NH}_{4}-\mathrm{N}$ and $\mathrm{NO}_{\mathrm{X}}-\mathrm{N}$. Measurement of $\mathrm{TN}$ in the plant biomass can be used as an indicator to estimate the capacity of the plants to uptake and assimilate nitrogen. Table 7 shows a summary of the biomass $\mathrm{N}$ in the plants used in the experiment.

$\mathrm{TN}$ ( $\mathrm{g} \mathrm{N} /$ plant) in the Melaleuca trees in March and July 2015 ranged from 6.1 (BC5) - 8.0 (BC25) $\mathrm{g} \mathrm{N} /$ plant and 9.8 (BC20) - 10.4 (SCP) $\mathrm{g} \mathrm{N}$ /plant, respectively. The biomass $\mathrm{N}$ in the Lemongrass $(C$. citratus) ranged from 2.6 (BC10) - 3.2 (BC5) $\mathrm{g} \mathrm{N} /$ plant and $3.6 \mathrm{~g} \mathrm{~N} /$ plant for the March and July 2015, respectively. The TN biomass for each treatment ranged from 9.3 (BC5) - 11.0 (BC25) $(\mathrm{g} \mathrm{N})$ and 13.4 
Table 5

Significant differences of $\mathrm{TN}, \mathrm{NH}_{4}-\mathrm{N}$, and $\mathrm{NO}_{\mathrm{x}}-\mathrm{N}$ loaded with septage among the treatments $(\alpha<0.05)$

\begin{tabular}{llllllll}
\hline & S100 & SCP & BC5 & BC10 & BC15 & BC20 & BC25 \\
\hline S100 & - & - & $\mathrm{x} \cdot$ & $\mathrm{x} \cdot$ & $+\mathrm{x} \cdot$ & $+\mathrm{x} \cdot$ & $+\mathrm{x} \cdot$ \\
SCP & - & - & $\mathrm{x} \cdot$ & $\mathrm{x} \cdot$ & $+\mathrm{x} \cdot$ & $+\mathrm{x} \cdot$ & $+\mathrm{x} \cdot$ \\
BC5 & $\mathrm{x} \cdot$ & $\mathrm{x} \cdot$ & - & - & - & $+\mathrm{x}$ & $+\mathrm{x}$ \\
BC10 & $\mathrm{x} \cdot$ & $\mathrm{x} \cdot$ & - & - & - & $+\mathrm{x}$ & $+\mathrm{x}$ \\
BC15 & $+\mathrm{x} \cdot$ & $+\mathrm{x} \cdot$ & - & - & - & - & - \\
BC20 & $+\mathrm{x} \cdot$ & $+\mathrm{x} \cdot$ & $+\mathrm{x}$ & $+\mathrm{x}$ & - & - & - \\
BC25 & $+\mathrm{x} \cdot$ & $+\mathrm{x} \cdot$ & $+\mathrm{x}$ & $+\mathrm{x}$ & - & - & - \\
\hline
\end{tabular}

$\mathrm{x}$ : significant difference of TN $(\alpha<0.05)$.

+ : significant difference of $\mathrm{NH}_{4}-\mathrm{N}(\alpha<0.05)$.

$\because$ significant difference of NOx-N $(\alpha<0.05)$.

-: no significant differences.

Table 6

Removal efficiency of $\mathrm{TN}, \mathrm{NH}_{4}-\mathrm{N}$, and $\mathrm{NO}_{\mathrm{x}}-\mathrm{N}(\%)(x \pm \mathrm{SD})$ loaded with septage among the treatments.

\begin{tabular}{lllll}
\hline \multirow{2}{*}{ N Species } & \multicolumn{3}{l}{ Media treatment } \\
\cline { 2 - 5 } & S100 & BC5 & BC10 & BC20 \\
\hline $\mathrm{TN}(\%)$ & $63.1 \pm 3.2$ & $70.8 \pm 3.1$ & $72.7 \pm 3.0$ & $78.9 \pm 2.2$ \\
$\mathrm{NH}_{4}-\mathrm{N}(\%)$ & $65.9 \pm 2.9$ & $69.4 \pm 2.7$ & $70.5 \pm 3.8$ & $78.8 \pm 2.7$ \\
$\mathrm{NO}_{\mathrm{x}}-\mathrm{N}(\%)$ & $68.5 \pm 3.2$ & $79.9 \pm 2.9$ & $83.1 \pm 2.2$ & $86.7 \pm 2.2$ \\
\hline
\end{tabular}

(BC20) - 14.0 (SCP) ( $\mathrm{g} \mathrm{N}$ ) for the March and July 2015, respectively. One-way ANOVA analysis showed that there were no significant differences of $\mathrm{N}$ biomass between BC5, BC10, BC15, and BC25 harvested in March 2015 and between S100, SCP, and BC20 harvested in July 2015. This indicated that the addition of biochar in the sand media did not increase plant $\mathrm{N}$ biomass. In agroforestry, applying biochar into the soil system can increase plant growth and crop yields (Atkinson et al., 2010; Lehmann and Joseph, 2012). In our experiment, however, addition of biochar did not improve the plant biomass. This may be due to the high nutrient concentrations of $\mathrm{NO}_{\mathrm{x}}-\mathrm{N}$ and $\mathrm{NH}_{4}-\mathrm{N}$ in the wastewater loaded into the mesocosms providing sufficient nutrients for growth even in pure sand media.

The results of biomass $\mathrm{N}$ in Melaleuca trees were higher compared to the results obtained by Bolton and Greenway (1997) and Greenway (2013). Bolton and Greenway (1997) reported $7.3 \mathrm{~g} \mathrm{~N} /$ plant after growing for 21 months in the sand media continuously saturated with secondary effluent; while Greenway (2013) reported only $5.92 \mathrm{~g} \mathrm{~N} /$ plant after growing for 24 months in sand media (80\%) augmented with water treatment residuals (20\%) and intermittently loaded with tertiary effluent. These results all confirm that Melaleuca plants can tolerate a range of effluent types and nitrogen concentrations, with enhanced growth occurring at higher nitrogen availability.

To the best of the authors' knowledge, this is the first study to determine plant biomass $\mathrm{N}$ in Lemongrass. Lemongrass and Vetiver plants are classified as perennial grasses and their morphological characteristics are closely related (Rao, 2013). The Vetiver plant has a high tolerance to drought, flood, and inundation and it has a high capacity to absorb nutrients from wastewater (Ash and Truong, 2003; Kantawanichkul et al., 2013). Therefore, the biomass $\mathrm{N}$ accumulation in the Lemongrass plants was compared to that in the Vetiver plants. Our results show that the plant biomass $\mathrm{N}$ in the Lemongrass (C. citratus) was comparable to Vetiver (Chrysopogon zianioides) biomass N (2.4 g N/ plant) (Greenway, 2013). Thus, Lemongrass has the potential to be used for wastewater treatment.

\section{Conclusion}

The addition of biochar to sand media, in mesocosm scale constructed wetland experiments, improved nitrogen removal efficiencies from both secondary clarified wastewater and septage. Regression analysis showed strong positive correlation between biochar content of the media and nitrogen removal efficiency. However, statistically significant differences in nitrogen outflow concentrations were only observed between treatments when the biochar: sand increment differed by more than $10 \%$ (i.e. between $0 \%$ and $10 \%, 5 \%$ and $15 \%, 10 \%$ and $20 \%$ ). Positive correlations were also observed between TN and $\mathrm{BOD}_{5}$ removal efficiency for the mesocosm. The correlation between nitrogen and $\mathrm{BOD}_{5}$ removal was particularly strong when the mesocosms were intermittently loaded with septage. $\mathrm{N}$ biomass in plants harvested after 21 months was similar for both pure sand media and the biochar augmented media. Biochar amendment did not improve plant growth; however, the high nitrogen concentrations in the wastewater would have provided sufficient nutrients for growth.

\section{Acknowledgements}

At the time of writing this paper, Philiphi de Rozari was a $\mathrm{PhD}$ student supported by Australian Development Scholarship (ADS). The research was conducted at the Loganholme Water Pollution Control Centre and the authors would like to acknowledge Steve Walter, the supervisor treatment operations. Special thanks are also given to Scott Byrnes James Canon for their assistance in chemical analysis and plant analysis.

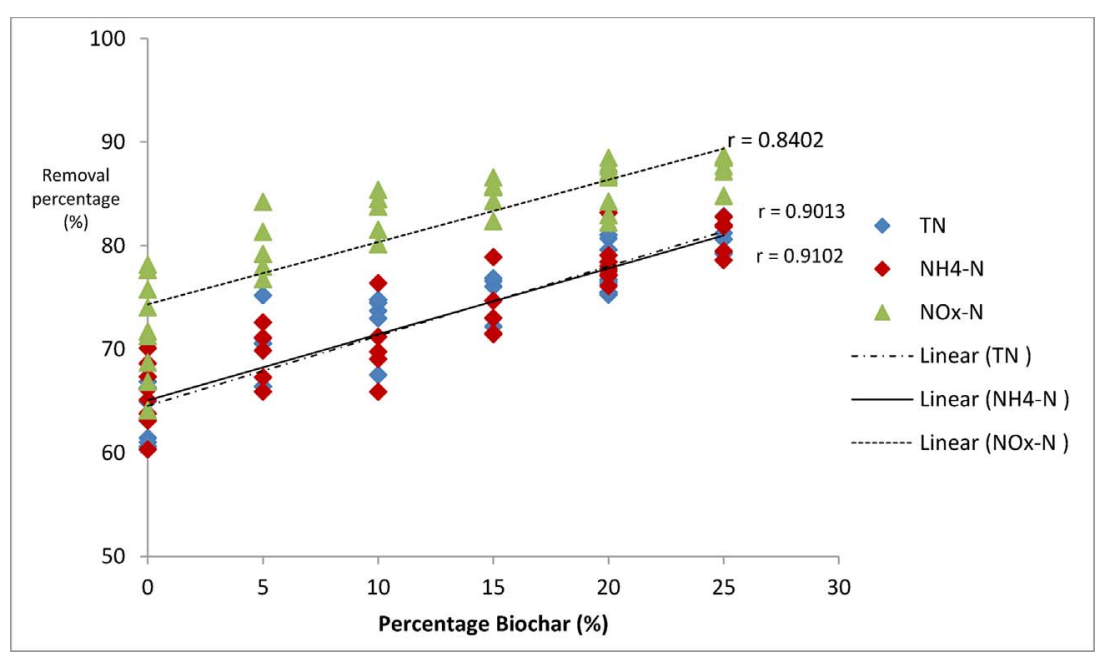

Fig. 5. Regression analyses of biochar content (\%) vs removal percentage of nitrogen compounds (\%) in the VF mesocosms loaded with septage. 


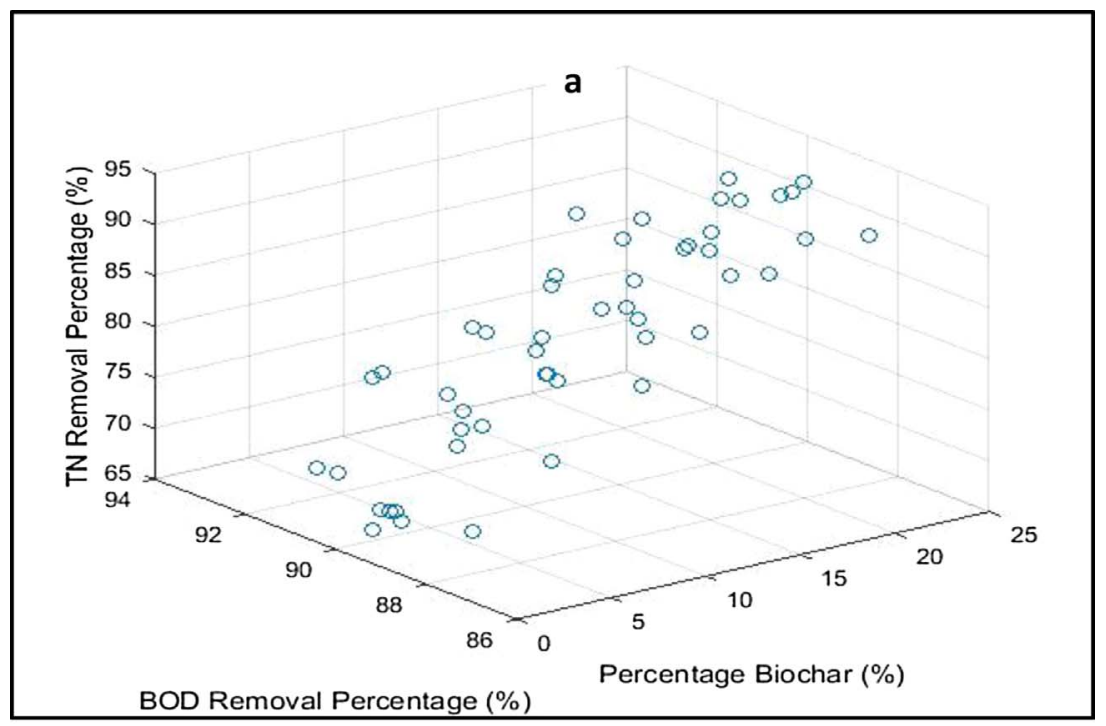

Fig. 6. TN removal (\%) vs $\mathrm{BOD}_{5}$ removal (\%) and biochar content in the VF mesocosms loaded with (a) SCW and b (septage).

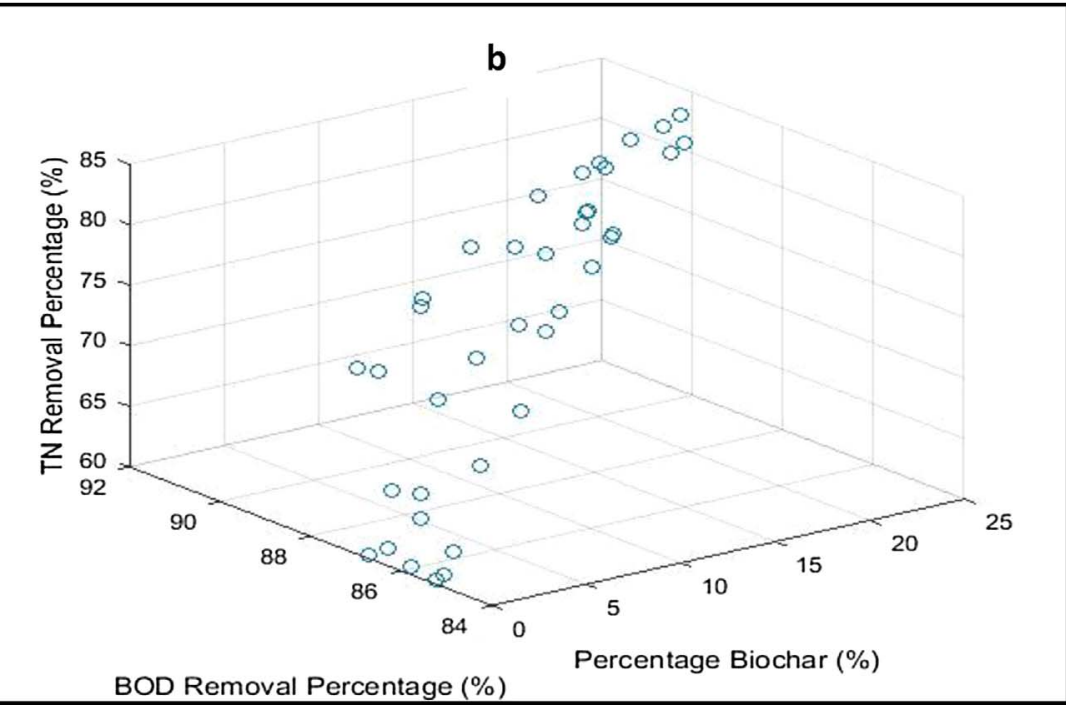

Table 7

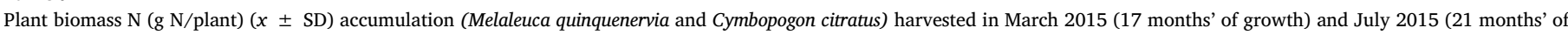
growth).

\begin{tabular}{|c|c|c|c|c|c|c|c|}
\hline \multirow[t]{2}{*}{ Plants biomass $\mathrm{N}$} & \multicolumn{7}{|l|}{ Treatment } \\
\hline & $\mathrm{S} 100^{\mathrm{a}}$ & $\mathrm{SCP}^{\mathrm{a}}$ & BC5 & BC10 & BC15 & $\mathrm{BC} 20^{\mathrm{a}}$ & BC25 \\
\hline M. quinquenervia (g N/plant) & $10.0 \pm 1.0^{\mathrm{a}}$ & $10.4 \pm 0.5^{\mathrm{a}}$ & $6.1 \pm 1.0$ & $7.6 \pm 0.5$ & $7.8 \pm 0.9$ & $9.8 \pm 0.1^{\mathrm{a}}$ & $8.0 \pm 0.1$ \\
\hline C. citratus (g N/plant) & $3.6 \pm 0.6^{\mathrm{a}}$ & $3.6 \pm 0.6^{\mathrm{a}}$ & $3.2 \pm 1.4$ & $2.6 \pm 0.4$ & $2.8 \pm 0.3$ & $3.6 \pm 0.2^{\mathrm{a}}$ & $3.0 \pm 0.3$ \\
\hline Total (g N/mesocosm) & $13.6 \pm 0.5^{\mathrm{a}}$ & $14.0 \pm 0.9^{\mathrm{a}}$ & $9.3 \pm 0.8$ & $10.2 \pm 0.2$ & $10.6 \pm 0.9$ & $13.4 \pm 0.3^{\mathrm{a}}$ & $11.0 \pm 0.2$ \\
\hline
\end{tabular}

a Plant biomass harvested in July 2015.

\section{References}

APHA, 2005. Standard Methods for the Examination of Water and Wastewater. APHA, Washington DC, USA.

Abou-Elela, S.I., Golinielli, G., Abou-Taleb, E.M., Hellal, M.S., 2013. Municipal wastewater treatment in horizontal and vertical flows constructed wetlands. Ecol. Eng. 61, 460-468.

Ash, R., Truong, P., 2003. The use of Vetiver grass wetlands for sewerage treatment in Australia. In: Proc. Third International Vetiver Conference. Guangzhou, China.

Atkinson, C.J., Fitzgerald, J.D., Hipps, N.A., 2010. Potential mechanisms for achieving agricultural benefits from biochar application to temperate soils: a review. Plant Soil $337,1-18$.

Barnes, R.T., Gallagher, M.E., Masiello, C.A., Liu, Z., Dugan, B., 2014. Biochar-induced changes in soil hydraulic conductivity and dissolved nutrient fluxes constrained by laboratory experiments. PLoS One 9, e108340.
Bedient, P.B., Huber, W.C., 1988. Hydrology and Floodplain Analysis. Addison-Wesley, Reading, Massachusetts.

Bolton, K.G., Greenway, M., 1997. A feasibility study of Melaleuca trees for use in constructed wetlands in subtropical Australia. Water Sci. Technol. 35, 247-254.

Bradley, A., Larson, R., Runge, T., 2015. Effect of wood biochar in manure-applied sand columns on leachate quality. J. Environ. Qual. 44, 1720-1728.

Caselles-Osorio, A., García, J., 2007. Impact of different feeding strategies and plant presence on the performance of shallow horizontal subsurface-flow constructed wetlands. Sci. Total Environ. 378, 253-262.

Davis, A.P., Shokouhian, M., Sharma, H., Minami, C., 2006. Water quality improvement through bioretention media: nitrogen and phosphorus removal. Water Environ. Res. 284-293.

De Rozari, P., Greenway, M., El Hanandeh, A., 2015. An investigation into the effectiveness of sand media amended with biochar to remove BOD5, suspended solids and coliforms using wetland mesocosms. Water Sci. Technol. 71, 1536-1544. 
De Rozari, P., Greenway, M., El Hanandeh, A., 2016. Phosphorus removal from secondary sewage and septage using sand media amended with biochar in constructed wetland mesocosms. Sci. Total Environ. 569, 123-133.

Güereña, D., Lehmann, J., Hanley, K., Enders, A., Hyland, C., Riha, S., 2013. Nitrogen dynamics following field application of biochar in a temperate North American maize-based production system. Plant Soil 365, 239-254.

Gautam, D., Greenway, M., 2014. Nutrient accumulation in five plant species grown in bioretention systems dosed with wastewater. Australas. J. Environ. Manag. 21, 453-462.

Greenway, M. A decade of bioretention research. 8th International Water Sensitive Urban Design Conference 25-28 November 2013 Surfers Paradise Gold Coast. Published in Water Sensitive Urban Design 2013: WSUD 2013/Engineers/Australia., pp. 21-31.

Gul, S., Whalen, J.K., Thomas, B.W., Sachdeva, V., Deng, H., 2015. Physico-chemical properties and microbial responses in biochar-amended soils: mechanisms and future directions. Agric. Ecosyst. Environ. 206, 46-59.

Gupta, P., Ann, T.-W., Lee, S.-M., 2015. Use of biochar to enhance constructed wetland performance in wastewater reclamation. Environ. Eng. Res. 21, 36-44.

Jassal, R.S., Johnson, M.S., Molodovskaya, M., Black, T.A., Jollymore, A., Sveinson, K., 2015. Nitrogen enrichment potential of biochar in relation to pyrolysis temperature and feedstock quality. J. Environ. Manag. 152, 140-144.

Kadlec, R.H., Wallace, S., 2008. Treatment Wetlands. CRC Press.

Kameyama, K., Miyamoto, T., Shiono, T., Shinogi, Y., 2012. Influence of sugarcane bagasse-derived biochar application on nitrate leaching in calcaric dark red soil. J. Environ. Qual. 41, 1131-1137.

Kantawanichkul, S., Sattayapanich, S., Van Dien, F., 2013. Treatment of domestic wastewater by vertical flow constructed wetland planted with umbrella sedge and Vetiver grass. Water Sci. Technol. 68, 1345-1351.

Kizito, S., Wu, S., Kirui, W.K., Lei, M., Lu, Q., Bah, H., Dong, R., 2015. Evaluation of slow pyrolyzed wood and rice husks biochar for adsorption of ammonium nitrogen from piggery manure anaerobic digestate slurry. Sci. Total Environ. 505, 102-112.

Kizito, S., Lv, T., Wu, S., Ajmal, Z., Luo, H., Dong, R., 2017. Treatment of anaerobic digested effluent in biochar-packed vertical flow constructed wetland colums: role of media and tidal operation. Sci. Total Environ. 592, 197-205.

Lehmann, J., Joseph, S., 2012. Biochar for Environmental Management: Science and Technology. Routledge.

Lucas, W.C., Greenway, M., 2011a. Hydraulic response and nitrogen retention in bioretention mesocosms with regulated outlets: part I-hydraulic Response. Water Environ. Res. 83, 692-702.

Lucas, W.C., Greenway, M., 2011b. Hydraulic response and nitrogen retention in bioretention mesocosms with regulated outlets: part II-nitrogen retention. Water Environ. Res. 83, 703-713.

Millot, Y., Troesch, S., Esser, D., Molle, P., Morvannou, A., Gourdon, R., et al., 2016. Effects of design and operational parameters on ammonium removal by single-stage
French vertical flow filters treating raw domestic wastewater. Ecol. Eng. 97, 516-523.

Mohan, D., Sarswat, A., Ok, Y.S., Pittman, C.U., 2014. Organic and inorganic contaminants removal from water with biochar, a renewable, lowcost and sustainable adsorbent - a critical review. Bioresour. Technol. 160, 191-202.

Mukherjee, A., Zimmerman, A., Harris, W., 2011. Surface chemistry variations among a series of laboratory-produced biochars. Geoderma 163, 247-255.

Rao, E.P., 2013. Aromatic plant species in agricultural production systems based on marginal soils. Plant Sciences Reviews 2012. CAB International, Boston 105.

Saeed, T., Sun, G., 2012. A review on nitrogen and organics removal mechanisms in subsurface flow constructed wetlands: dependency on environmental parameters, operating conditions and supporting media. J. Environ. Manag. 112, 429-448.

Sarkhot, D.V., Berhe, A.A., Ghezzehei, T.A., 2012. Impact of biochar enriched with dairy manure effluent on carbon and nitrogen dynamics. J. Environ. Qual. 41, 1107-1114.

Tan, X., Liu, Y., Zeng, G., Wang, X., Hu, X., Gu, Y., Yang, Z., 2015. Application of biochar for the removal of pollutants from aqueous solutions. Chemosphere 125, 70-85.

USEPA, 1983. Methods for Chemical Analysis of Water and Wastes. Environmental Monitoring System Laboratory EPA, Cincinnati, USA.

Wang, Z., Guo, H., Shen, F., Yang, G., Zhang, Y., Zeng, Y., Wang, L., Xiao, H., Deng, S., 2015. Biochar produced from oak sawdust by Lanthanum (La)-involved pyrolysis for adsorption of ammonium ( $\mathrm{NH} 4+$ ), nitrate (NO 3-), and phosphate (PO $43-$ ). Chemosphere 119, 646-653.

Wu, H., Fan, J., Zhang, J., Ngo, H.H., Guo, W., Hu, Z., Liang, S., 2015. Decentralized domestic wastewater treatment using intermittently aerated vertical flow constructed wetlands: impact of influent strengths. Bioresour. Technol. 176, 163-168.

Yao, Y., Gao, B., Zhang, M., Inyang, M., Zimmerman, A.R., 2012. Effect of biochar amendment on sorption and leaching of nitrate, ammonium, and phosphate in a sandy soil. Chemosphere 89, 1467-1471.

Zhang, D.Q., Tan, S.K., Gersberg, R.M., Zhu, J., Sadreddini, S., Li, Y., 2012. Nutrient removal in tropical subsurface flow constructed wetlands under batch and continuous flow conditions. J. Environ. Manag. 96, 1-6.

Zhang, D.-Q., Jinadasa, K., Gersberg, R.M., Liu, Y., Tan, S.K., Ng, W.J., 2015. Application of constructed wetlands for wastewater treatment in tropical and subtropical regions (2000-2013). J. Environ. Sci. 30, 30-46.

Zheng, H., Wang, Z., Deng, X., Herbert, S., Xing, B., 2013. Impacts of adding biochar on nitrogen retention and bioavailability in agricultural soil. Geoderma 206, 32-39.

Zhou, X., Wang, X., Zhang, H., Wu, H., 2017. Enhanced nitrogen removal of low C/N domestic wastewater using biochar-amended aerated vertical flow constructed wetland. Bioresour. Technol. 241, 269-275.

Zurita, F., De Anda, J., Belmont, M., 2009. Treatment of domestic wastewater and production of commercial flowers in vertical and horizontal subsurface-flow constructed wetlands. Ecol. Eng. 35, 861-869. 